\title{
The Role of Public Service Quality in Increasing Satisfaction to Realize Community Welfare
}

\author{
Dody Kusmayadi \\ Lecturer of Public Administration, Universitas Majalengka, Indonesia \\ dodykusmayadi3@gmail.com
}

DOI: 10.29322/IJSRP.12.01.2022.p12135

http://dx.doi.org/10.29322/IJSRP.12.01.2022.p12135

\begin{abstract}
The main problem in this study is whether the public service quality affects community satisfaction in the pasirmuncang village office of Panyingkiran District of Majalengka Regency. This research aims to determine the effect of public service quality on community satisfaction at Pasirmuncang Village Office of Panyingkiran District majalengka regency. The data collection methods used in this research are literature studies and field research. The population in this study is the entire community served in Pasirmuncang Village of Panyingkiran District of Majalengka Regency as 1,278 people during the sample in this study as many as 305 people. The analysis method used is a simple linear regression; the study results stated that the public service quality had a positive and significant effect on community satisfaction in the Pasirmuncang Village Office of Panyingkiran District Majalengka Regency.
\end{abstract}

Keywords: Public service quality, Community Satisfaction, Community Welfare

\section{INTRODUCTION}

$\mathrm{L}$ aw No. 23 of 2014 on Local Government explained that the Village is a unitary legal community that has territorial boundaries that are authorized to regulate and manage Government Affairs, the interests of the local community based on community initiatives, origin rights, or traditional rights that are recognized and respected in the system of government of the Unitary State of the Republic of Indonesia. To carry out the mandate of the local government implementation law, the government needs the support of a government apparatus that is resilient, professional, and able to do local and compete globally.

Public service is all service activities carried out by public service providers to meet public needs and implement the provisions of the Laws and Regulations. Implementation of public services, government apparatus, creates welfare (Copeland \& Wexler, 2015; Dewi et al., 2019; Riccucci et al., 2004). The community is entitled to get the best service from the government because it has provided its funds in tax payments, levies, and various other levies, following the Law of the Republic of Indonesia Number 25 of 2009 on Public Services, that the community is entitled to quality services following the principles and purposes of service. The primary purpose of public service is the satisfaction of the community.

Community satisfaction can be realized if the service provided is following service standards or has been better than the standard of service that has been set (Copeland \& Wexler, 2015; Dewi et al., 2019; Riccucci et al., 2004). Therefore, the method used to measure community satisfaction and the public service qualitys provided is to use the Community Satisfaction Index contained in the Decree of the Minister of Utilization of State Apparatus Number KEP/25/M.PAN/2/2004 dated February 24, 2004, on General Guidelines for The Preparation of Community Satisfaction Index of Government Agency Service Units. The community satisfaction index is data and information about the level of community satisfaction obtained from quantitative measurements of public opinion in obtaining services from the public service organizing apparatus by comparing their expectations and needs. Public Service is any activity to meet basic needs following the fundamental rights of every citizen or resident or administrative goods, services, and services provided by service providers related to the public interest.

Good service is essential in maintaining customers (Sari, Sulva Widya, Sunaryo, 2018) because good forms of service can attract attention from the public. Well-managed services are expected to meet community expectations because the community has a big role in comparing satisfaction and quality evaluation standards. Community satisfaction compares the community's beliefs, namely the customer itself that will be received, with the public service quality it receives in the form of performance. The public service quality is perceived as satisfactory and good, and if the public service quality provided exceeds the expectations of the community perceived ideally. Along with the development of society, the need for increasingly complex services and better, faster, and appropriate services is needed by the community. The apparatus during the community must be able to provide services that follow the community's needs, 
so that community satisfaction is met. In carrying out its duties, the apparatus is a subsystem of government administration that has the authority to organize and manage its households in power and successful manner following government development.

On the other hand, village devices are often constructed as village pumps expected to become community protectors. But there is still the management of the village government in this context which is still weak in the accountability and transparency of the village government. Often, institutional changes in the village inevitably encourage the village's human resources (apparatus) to work following the targets to be achieved. For this reason, the village officials must be able to work optimally. Human resources are no longer viewed as one of the factors of production, as ancient management argues, which treated humans like machines. But now, the village apparatus is a Human Capital that plays a very role following the views of modern management. This is as the results of research conducted by (Chaddha et al., 2020) that human capital has a role in management in improving organizational performance, while research conducted by (Zeb et al., 2018) that human capital has a vital role in improving employee performance.

That difference in views brings an indication of the treatment of human resources. At first glance, human resources are managed in parallel with production management. Finance and marketing are certainly not following the dignity of human dignity. Because humans are not just a source but an implementation that runs the institution or motor steering organization. People in general still often complain about village government officials who lack understanding of the needs of residents. To obtain a simple service, people often face difficulties, such as convoluted procedures. Village government officials do not feel called to improve efficiency and improve work procedures.

\section{LITERATURE REVIEW}

\section{a. Public Service Quality}

Public service can be said to be quality if it follows the expectations or desires of service recipients. The community as service users can find out whether the public services provided by the government are following the wants and needs of the community as service users if the quality of public services must be measured and assessed by the community as service users. This follows the opinion (Lukman, 2000, p. 12), which states, "The service quality is successfully built if the service provided to customers gets recognition from the parties served. Recognition of the primitiveness of service does not come from the apparatus that provides services but comes from service users."

The above understandings can be concluded that the quality of public services is a dynamic condition related to products, services, people, processes, and the environment where the quality assessment is determined at the time of the occurrence of public services. Determining the public service quality provided is an assessment of the service recipient based on the customer's point of view and perception of the services obtained. The perception of customer assessment of the service provided is a thorough assessment of a service assessment, so it can be said that a quality service is based on customer satisfaction. If satisfaction is created, the perception of quality service will grow.

Each service will produce a variety of assessments that come from the parties served or customers. Good service will certainly provide good judgment from customers. Still, if the service provided does not provide satisfaction, it will cause customer disappointment and can worsen the image of the service provider agency. To assess the extent of the quality of public services provided by the government apparatus, there need to be criteria that show whether a given public service can be done good or bad, quality or not. According to the internal Parasuraman (Hardiyansyah, 2011, p. 46), the service quality can be measured from 5 dimensions: Tangible, which consists of physical facilities, equipment, personnel, and communication. Reliability is based on service units' ability to create the service promised appropriately. Responsiveness, the willingness to help consumers take responsibility for the public service quality provided. Assurance, including knowledge, ability, decency, and trustworthiness possessed by staff, free from danger, risk or doubt, and empathy, including ease of good communication relationships, personal attention, and understanding the needs of customer.

The product of a public organization is a public service. Therefore, quality service products become the demands of service recipients. It focuses on meeting the needs and desires of the community, according to Pasuranman (F. Tjiptono, 2008, p. 108), identifying 10 basic dimensions of service among them; reliability, responsiveness, competence, access, courtesy, communication, credibility, security, customer understanding ability, physical evidence. Based on the description, the dimension of public service quality can be used as a benchmark to realize quality services to satisfy the community's expectations.

\section{b. Community Satisfaction}

Community satisfaction can be shown through the community's attitude after obtaining the results obtained. Public satisfaction will be seen from how well the results are obtained and felt. The better the quality of the results obtained, the better customer satisfaction. The word satisfaction, according to (F. dan G. C. Tjiptono, 2011, p. 433), comes from the Latin "satis," which means quite good, adequate, and "faction," which means to do or make. Satisfaction can be interpreted as "efforts to fulfill something" or "make something adequate."

People are the main customers who get the service. Government employees will provide the best service to achieve community satisfaction. Therefore, measuring the level of community satisfaction is very necessary because it will provide useful information for 
the agency's development. Tse and Wilton (Lupiyoadi, 2016) explain: "Customer satisfaction or dissatisfaction is the customer's response to the evaluation of perceived disconfirmation between previous expectations and the actual performance of the product felt after its use." Government agencies can find out the community's satisfaction through feedback provided by the community to the service provider agency so that it can be an input for the needs of development and implementation and increase community satisfaction..

Examples of feedback can be known when the community complains or complains; with the complaint or complaint, the agency can improve and improve the service to satisfy the unsatisfied community. Wilkie (F. dan G. C. Tjiptono, 2011, p. 433) defines "Customer satisfaction as an emotional response to an evaluation of the consumption experience of a product or service." Emotional responses can be more feelings felt when something he expects is achieved. People who constantly and repeatedly come to the same place without complaints to use the product or service can be told that they are satisfied with the product or service that the agency has provided.

Public satisfaction with public organizations is very important because of public trust. According to (Harbani Pasolong, 2011, p. 221), "The better the government and the public service quality provided, the higher the public trust (high trust)." Public trust will be higher if the community gets good service and feels satisfied with the service. The Decree of the Minister of Utilization of State Apparatus No. 63 of 2003 on The General Guidelines for the Implementation of Public Services states that "The measure of the success of service implementation is determined by the level of satisfaction of service recipients. Service satisfaction is achieved when the service recipient obtains the service following what is needed and expected." Customer satisfaction can be measured using various kotler measurement methods in (F. Tjiptono, 2008), simply proposing four methods that can measure customer satisfaction, namely the Customer-oriented Complaints and Advice System. Every customer-oriented company needs to provide the widest opportunity for its customers to convey suggestions, opinions, and complaints. Media that can be used are suggestion boxes, comment cards, special phone lines (customer hotlines), and others.

Through the survey, the company will get responses and feedback directly from customers and at the same time also give a positive signal that the company pays attention to its customers. Ghost Shopping This method is done by hiring several people (ghost shoppers) to play or act as potential customers of company products and competitors. Then the ghost shopper conveyed his findings of the strengths and weaknesses of the company's products and competitors based on their experience. Lost Customer Analysis Companies use this method to analyze customer satisfaction by contacting customers who have stopped buying or switched suppliers. The results of this method will be obtained information on the cause of this occurrence. This information is very useful for companies to take the next policy steps to increase customer satisfaction and loyalty.

Based on the description, four methods can measure community satisfaction: complaint or suggestion system methods, customer satisfaction surveys, ghost shopping methods, and lost customer analysis. While according to (Consuegra. D Molina, 2007), measuring customer satisfaction can be through 3 dimensions: Conformity of expectations: Products or services offered following customers' expectations. Performance perception: Performance results received by customers on the part of the company have been very good or not, and customer ratings: Overall, the service received by customers is better or not when compared to other companies that offer the same product or service.

The measurement of satisfaction levels is closely related to the public service quality. Measuring quality aspects is useful for government agencies to know well the course of the agency's service process, know where to make changes to make continuous improvements to satisfy the community, determine changes that lead to improvement. Indicators of public satisfaction are complaints and advice systems, customer satisfaction surveys, Ghost shopping methods, lost customer analysis, expectation conformity, performance perception, customer assessment. Customer satisfaction can be measured based on these indicators. In this study, customer satisfaction will be measured using indicators from (Consuegra. D Molina, 2007), namely conformity of expectations, performance perception, customer assessment. The selection of these indicators due to the conformity of expectations will determine the quality of the services carried out in rowosari village hall office, performance perception to obtain a public opinion about employee work discipline, customer assessment is used to assess whether or not the service provided by Rowosari Village Hall Office to the community when compared to other Village Hall Offices. This study only took three indicators while four indicators, namely complaints and advice systems, customer satisfaction surveys, Ghost shopping methods, and lost customer analysis, were not used due to implementation difficulties.

\section{RESEARCH METHODS}

The purpose of survey research is to provide a detailed picture of the background, traits, and characteristics typical of the case or status of the individual, which then of these characteristics will be made a general thing. The method used in this study is a descriptiveanalytical method with a survey approach. The purpose of this descriptive research is to make descriptions, images, or paintings systematically, factually, and accurately about the facts, properties, and relationships between the phenomena investigated.

This type of research data relates to the data source and the selection of methods that the author uses to obtain the research data. The type of data collected in research for variables in the quality of public services and community satisfaction is semi-quantitative data (ordinal scale), which is answers questions about the quality of public services and community satisfaction. The source of research data

This publication is licensed under Creative Commons Attribution CC BY.

http://dx.doi.org/10.29322/IJSRP.12.01.2022.p12135

WWW.ijsrp.org 
is an important factor in the author's consideration in determining the data collection method. The two data sources used in this study are primary and secondary data.

The population in this study was based on the number of Family Heads of 1,278 people consisting of 18 RT and 8 RW. Based on the data, the number of samples from the population to be used as research subjects using the slovin formula with an error rate of 5\%. Based on the calculation of slovin, the minimum number of samples taken is as many as 305 people. The method used to determine which region to sample is the sample withdrawal technique based on the region cluster. The cluster of regions taken is adjusted to Neighborhood association (RT) as many as 18 RT in Pasirmuncang Village. Data has a very important position because it describes the variables studied and proves the hypothesis. Therefore, whether or not the data determines the quality of the data instrument. A questionnaire as a good instrument must meet two requirements, namely valid and reliable.

Hypothesis testing is intended to determine whether or not there is a significant influence between public service quality variables on community satisfaction variables. In testing this hypothesis, researchers determined using significant tests to determine the null hypothesis ( $\mathrm{Ho})$ and the alternative hypothesis $(\mathrm{Ha})$. The null hypothesis $(\mathrm{Ho})$ is a hypothesis that states that there is no significant influence between independent variables and dependent variables. In contrast, the alternative hypothesis (Ha) is a hypothesis that states that there is a significant influence between independent variables and dependent variables.

\section{RESEARCH RESULT AND DISCUSSION}

\section{a. Test validity and reliability}

Data can be valid if the data is used to measure what should be measured. While reliability is used to show consistency and stability of the value of a particular measurement scale, thus reliability focuses on the issue of measurement accuracy and results. In this study, researchers tested the validity and reliability of data using Microsoft Excel 2010 and SPSS version 22.0.

Table 1. Validity Test

\begin{tabular}{ccccc}
\hline No. & Variable & $r$-value & r-table & Description \\
\hline 1 & Public service quality & $0,300-0,630$ & 0,300 & Valid \\
2 & Community satisfaction & $0,338-0,630$ & 0,300 & Valid \\
\hline
\end{tabular}

Source: Research data, 2020

The table about the test validity of the learning process variable obtained an r-calculate value greater than the r-table value of 0.300 . The results obtained that all instruments on public service quality variables have a fairly good validity value. Based on the table on the validity test of the public satisfaction variable obtained an $r$-value greater than the $r$-table value of 0.300 . The results obtained that all instruments on the community satisfaction variable have a fairly good validity value.

Table 2. Reliability Test

\begin{tabular}{clccc}
\hline No. & Variable & Alpha cronbach & r-table & Description \\
\hline 1 & Public service quality & 0.719 & 0.600 & Reliable \\
2 & Community satisfaction & 0.718 & 0.600 & Reliable \\
\hline
\end{tabular}

Source: Research data, 2020

Based on the table on reliable tests of village head leadership variables, apparatus performance, public service quality and community satisfaction obtained Alpha cronbach value greater than the r-table value of 0.600 . The results obtained that all instruments on the leadership variables of the village head, the performance of the apparatus, the public service quality and community satisfaction have a fairly good reliable value.

\section{b. Descriptive Analysis of Public service quality Variables}

The results of the analysis of public service quality variables are described in the table as follows:

Table 3. Description of Public service quality Variables 


\begin{tabular}{|c|c|c|c|c|c|c|c|c|}
\hline No. & Indicator & 5 & 4 & 3 & 2 & 1 & Average & Category \\
\hline 1 & Response of service personnel to citizen complaints & 98 & 133 & 55 & 18 & 1 & 4.01 & High \\
\hline 2 & $\begin{array}{l}\text { Response of service personnel to citizen advice and } \\
\text { criticism }\end{array}$ & 150 & 84 & 59 & 12 & 0 & 4.22 & High \\
\hline 3 & Reliability of officers in providing service information & 137 & 128 & 35 & 4 & 1 & 4.30 & High \\
\hline 4 & $\begin{array}{l}\text { Reliability of officers in carrying out procedures and } \\
\text { technical services }\end{array}$ & 148 & 127 & 29 & 1 & 0 & 4.38 & High \\
\hline 5 & $\begin{array}{l}\text { The ability of administrative and technical officers in } \\
\text { providing services }\end{array}$ & 165 & 121 & 19 & 0 & 0 & 4.48 & High \\
\hline 6 & The social attitude of officers in providing services & 101 & 88 & 108 & 7 & 1 & 3.92 & High \\
\hline 7 & The attention of service personnel & 114 & 101 & 60 & 25 & 5 & 3.96 & High \\
\hline 8 & Care of service personnel & 91 & 124 & 47 & 38 & 5 & 3.85 & High \\
\hline 9 & The waiting room and service counter & 92 & 146 & 45 & 20 & 2 & 4.00 & High \\
\hline 10 & The appearance of the service officer & 173 & 61 & 52 & 14 & 5 & 4.01 & High \\
\hline & Total & 1269 & 1113 & 509 & 139 & 20 & 41.13 & \\
\hline & Score & \multicolumn{7}{|c|}{3050} \\
\hline & Average & \multicolumn{7}{|c|}{4.113} \\
\hline & Category & \multicolumn{7}{|c|}{ High } \\
\hline
\end{tabular}

Source: Research data, 2020

The results of the analysis of descriptions of public service quality variables were obtained that 3 indicators included the ability of officers, the reliability of officers, and the openness of service information systems that were considered to have satisfied the community. Other findings on public service quality variables found that other indicators are considered not maximal, including the familiarity of officers with the community, the attention of officers in providing services, and the care of officers, which is the lowest assessment compared to other indicators. Therefore, attention to the three indicators needs to be improved considering the function of the village government is to provide services to the community.

\section{c. Descriptive Analysis of Community Satisfaction Variables}

The results of the analysis of community satisfaction variables are outlined in the table as follows:

Table 4. Description of Community Satisfaction Variables

\begin{tabular}{|c|c|c|c|c|c|c|c|c|}
\hline No. & Indicator & 5 & 4 & 3 & 2 & 1 & Average & Category \\
\hline 1 & Ease of service procedures & 163 & 106 & 33 & 3 & 0 & 4.41 & High \\
\hline 2 & Clarity of service procedures & 116 & 138 & 35 & 16 & 0 & 4.16 & High \\
\hline 3 & The harmony of service procedures & 156 & 73 & 74 & 2 & 0 & 4.26 & High \\
\hline 4 & Conformity of service requirements with the type of service & 133 & 134 & 24 & 11 & 3 & 4.26 & High \\
\hline 5 & Ease of taking care of and meeting service requirements & 116 & 136 & 37 & 10 & 6 & 4.13 & High \\
\hline 6 & Clarity on service requirements & 113 & 105 & 75 & 12 & 0 & 4.05 & High \\
\hline 7 & Certainty of the serving officer & 125 & 108 & 58 & 12 & 2 & 4.12 & High \\
\hline 8 & Ease of service officers & 196 & 56 & 19 & 30 & 4 & 4.34 & High \\
\hline 9 & The discipline of officers in providing services & 161 & 89 & 43 & 12 & 0 & 4.31 & High \\
\hline 10 & Ketepatan pelaksanaan terhadap jadwal waktu pelayanan & 177 & 73 & 47 & 4 & 4 & 4.36 & High \\
\hline 11 & Accuracy of implementation of the service schedule & 187 & 78 & 35 & 5 & 0 & 4.47 & High \\
\hline 12 & Certainty of responsibility from the service officer & 91 & 96 & 86 & 19 & 13 & 3.76 & High \\
\hline 13 & The intellectual ability of service personnel & 101 & 120 & 59 & 18 & 7 & 3.95 & High \\
\hline 14 & Administrative capabilities of service personnel & 130 & 98 & 67 & 9 & 1 & 4.14 & High \\
\hline 15 & Accuracy of service process & 162 & 112 & 25 & 6 & 0 & 4.41 & High \\
\hline 16 & Open time of service completion process & 197 & 71 & 33 & 4 & 0 & 4.51 & High \\
\hline & Total & 2324 & 1593 & 750 & 173 & 40 & & \\
\hline & Score & \multicolumn{7}{|c|}{4880} \\
\hline & Average & \multicolumn{7}{|c|}{4.22} \\
\hline & Category & \multicolumn{7}{|c|}{ High } \\
\hline
\end{tabular}

Source: Research data, 2020

The analysis of community satisfaction results obtained an average score of 4,223 , and this value belongs to the high category. The results of this study prove empirically that most of the community has been satisfied with the services provided by the village 
government, especially in the aspect of openness and responsibility in the completion of work related to the interests of the community. Both indicators are the highest average values compared to other indicators in the community satisfaction variable. However, two indicators need to be improved, namely the readiness of the village government apparatus and its competence, which is considered not yet maximal. It has the lowest average value compared to other indicators on community satisfaction variables.

\section{d.Path Analysis}

The results of the calculation of the path analysis for structure model, the effect of public service quality on community satisfaction, can be seen in the following image:

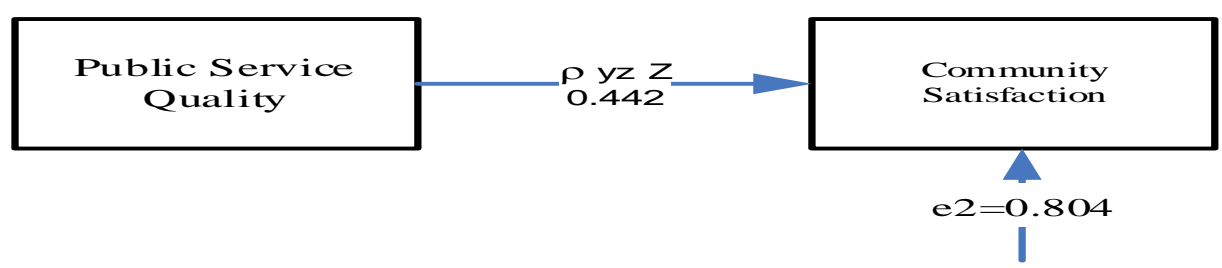

Figure 1. Results of Structural Model Analysis

From figure 1, it is seen that the value of the path coefficient between the public service quality variable and community satisfaction is 0.884 . These results indicate that the public service quality has a strong impact on public satisfaction by other variables outside the study influence $19.54 \%$, and the remaining $80.4 \%$.

\section{e. Hypothesis Test}

The hypothesis of public service quality to community satisfaction can be described as follows:

$$
\begin{array}{cll}
\mathrm{H}_{0}: \rho_{\mathrm{yz}}=0 & : & \text { The public service quality has no effect on people's satisfaction. } \\
\mathrm{H}_{1}: \rho_{\mathrm{yz}} \neq 0 & : & \text { The public service quality affects people's satisfaction. }
\end{array}
$$

Test of criteria: reject $\mathrm{H} 0$ if Sig. $<0.05$ or $\mathrm{t}$ value $>\mathrm{t}$ table.

Table 5. The effect of public service quality on community satisfaction

\begin{tabular}{lllll}
\hline Structural & $\begin{array}{c}\text { Path } \\
\text { coefficient }\end{array}$ & t value & Sign. & Description \\
\hline pxy & 0.442 & 8.583 & 0.000 & $\begin{array}{l}\text { Ho is rejected, there is an influence of } \\
\text { public service quality on community } \\
\text { satisfaction }\end{array}$ \\
\end{tabular}

$$
\text { Source: Spss Analysis Results Data, } 2020
$$

The calculation above shows the path coefficient value of 0.884 and the t-count value of 8,583 with a significance level $(\alpha)=5 \%$. the Sign value is obtained. $=0,000$. Following the results obtained, namely Sign. $(0.000)<0.05$ and t-value (8.583) > t-table (2.008) H0 is rejected, and $\mathrm{H} 1$ is accepted; thus, it can be concluded that the public service quality has a significant effect on public satisfaction..

The findings in this study are empirically proven that public service quality variables have a significant impact in providing satisfaction to the community. The influence of public service quality on community satisfaction was $19.54 \%$, and other variables outside the study influenced the remaining 80.4\%. These results are in line with research conducted by (Murniati \& Setyobakti, 2020; Syahrawanty Abbas et al., 2021) found that quality public services have a significant influence on public satisfaction, while the results of research results (Lukman; Agus; Muchlis, 2021) in his research suggested that to improve the public service quality it is necessary to pay attention to several aspects, including published terms of service, requirements that are easily met, published procedure information, clear service process flow, published service time, and fees/rates are communicated.

The results of this study reinforce the previous research conducted by (Desiyanti et al., 2018) that the public service quality has a positive and significant influence on the satisfaction of LPD Sembung Customary Village and LPD Adat Seseh Village, this means that the better the public service quality provided by LPD, customer satisfaction is increasing. Also, the worse the public service quality provided by LPD, customer satisfaction will decrease. While the findings of the study conducted by (Rizq et al., 2018) from 
the Importance Performance Analysis (IPA) showed the need for improvements in indicators of ease of management of requirements, speed of service processes and facilities, and physical condition of service office buildings.

\section{CONCLUSION}

The results of the study description of the public service quality are in the high category towards very high. However, there are still aspects that need to be improved, including the order in the service process. The results of the study description of public satisfaction are in the high category towards very high. However, there are still aspects that need to be improved including certainty in the service process. Verifikative research results prove empirically that the public service quality has a positive and partially significant effect on community satisfaction.

The efforts of the Village Government to adjust the amount of work produced by the apparatus following the targets set by the village government is to provide good incentives to encourage an increase in the quantity of work of the apparatus itself. With the provision of good incentives, the apparatus can be encouraged more eagerly, trying to adjust the amount of work produced following the targets set by the organization so that it will also have a positive impact on the overall performance of the organization. The efforts of the village government to encourage the apparatus to achieve the organization's target is to increase the level of discipline of the employee apparatus for the better. The built-up discipline of every good apparatus will foster the awareness of the apparatus's duties and responsibilities that the apparatus must carry out following applicable standards and regulations. The final result is expected to further contribute to improving the quality of public services. With some obstacles in serving the community, it is expected that the Village Government can face it and find a way out to answer the challenges of the community.

\section{ACKNOWLEDGMENT}

In this study, the researchers express their gratitude and appreciation to all parties who have helped carry out independent research activities carried out by researchers, especially lecturers at Majalengka University, West Java, Indonesia, who have helped researchers a lot from the observation stage, data collection, analysis, and conclusion.

\section{REFERENCES}

1. Chaddha, M. S., Khalique, F., \& Parimoo, D. (2020). Human Capital Management and Organisational Performance: A Literature Survey. Researchgate.Net, February, 1-14.

https://www.researchgate.net/profile/Fehmina_Khalique/publication/344863150_Human_Capital_Management_and_Organisational_Performance_A_Literature_S urvey/links/5f9463a2299bf1b53e4190d4/Human-Capital-Management-and-Organisational-Performance-A-Literature-Sur

2. Consuegra. D Molina. (2007). An Integrated Model of Price, Satisfaction and Loyality: An Empirical Analysis in Service Sector. Journal of Product \& Brand Management.

3. Copeland, V. C., \& Wexler, S. (2015). Policy implementation in social welfare: A Framework for analysis. Journal of Sociology \& Soical Welfare, 22(3), 51-68.

4. Desiyanti, N. L., Sudja, I. N., \& Budi Martini, L. K. (2018). Effect of Service Quality on Customer Satisfaction, Customer Delight and Customer Loyalty (Study on LPD Desa Adat Sembung and LPD Desa Adat Seseh). International Journal of Contemporary Research and Review, 9(03), $20660-20668$. https://doi.org/10.15520/ijcrr/2018/9/03/483

5. Dewi, I. K., Hardin, Sampara, S., Baharuddin, H., Nuh, M. S., Andara, D., Ramadhan, F. M., Haniarti, Rukka, R. M., \& Amrullah, A. (2019). Implementation of public services with a legal system approach in the "welfare state" framework to overcome disasters. IOP Conference Series: Earth and Environmental Science, 235(1). https://doi.org/10.1088/1755-1315/235/1/012025

6. Harbani Pasolong. (2011). Teori Administrasi Publik. Alfabeta.

7. Hardiyansyah. (2011). Kualitas Pelayanan Publik Konsep, Dimensi, Indikator dan Implementasinya. Gava Media.

8. Lukman; Agus; Muchlis. (2021). Service Quality and Consumer Satisfaction: An Empirical Study in Indonesia. The Journal of Asian Finance, Economics and Business, 8(5), 971-977. https://doi.org/10.13106/jafeb.2021.vol8.no5.0971

9. Lukman, S. (2000). Manajemen Kualitas Pelayanan. Stia Lan Press.

10. Lupiyoadi. (2016). Manajemen Pemasaran Jasa Teori dan Praktik. Salemba Empat.

11. Murniati, W., \& Setyobakti, M. H. (2020). Dimensions of Service Quality Satisfaction Community at the Village Government Office. Wiga : Jurnal Penelitian Ilmu Ekonomi, 10(1), 13-17. https://doi.org/10.30741/wiga.v10i1.456

12. Riccucci, N. M., Meyers, M. K., Lurie, I., \& Han, J. S. (2004). The Implementation of Welfare Reform Policy: The Role of Public Managers in Front-Line Practices. Public Administration Review, 64(4), 438-448. http://www.jstor.org/stable/3542493

13. Rizq, S., Djamaludin, M. D., \& Nurhadryani, Y. (2018). Analysis of Service Quality Satisfaction of E-Ktp Service At Public Administration and Civil Registration Office of Bogor District. Journal of Consumer Sciences, 3(2), 55. https://doi.org/10.29244/jcs.3.2.55-65

14. Sari, Sulva Widya, Sunaryo, M. (2018). the Effect of Service Quality on Customer Retention Through Commitment and Satisfaction As Mediation Variables in Java Eating Houses. Jurnal Aplikasi Manajemen, 16(4), 593-604. https://doi.org/10.21776/ub.jam.2018.016.04.05 


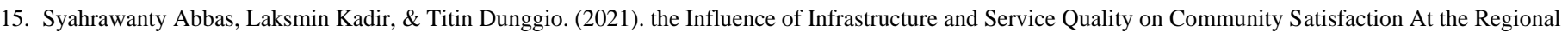
General Hospital Bumi Panua of Pohuwato Regency. Journal of Economic, Business, and Administration (JEBA), 2(1), 57-65. https://doi.org/10.47918/jeba.v2i1.210

16. Tjiptono, F. (2008). Strategi Pemasaran, Edisi III. Andi Offset.

17. Tjiptono, F. dan G. C. (2011). Service, Quality and Satisfaction, ed. 3. Andi Offset.

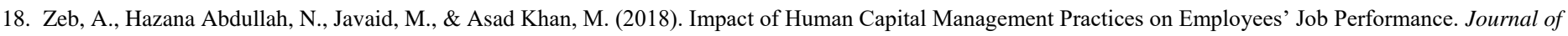
Physics: Conference Series, 1049(1). https://doi.org/10.1088/1742-6596/1049/1/012020

\section{AUTHORS}

Correspondence Author - Dody Kusmayadi, Lecturer of Public Administration, Universitas Majalengka, Indonesia and dodykusmayadi3@gmail.com. 